\title{
SET THE WORLD ON FIRE
}




\section{POLITICS AND CULTURE IN MODERN AMERICA}

\section{Series Editors:}

Margot Canaday, Glenda Gilmore, Michael Kazin, Stephen Pitti, Thomas J. Sugrue

Volumes in the series narrate and analyze political and social change in the broadest dimensions from 1865 to the present, including ideas about the ways people have sought and wielded power in the public sphere and the language and institutions of politics at all levels-local, national, and transnational. The series is motivated by a desire to reverse the fragmentation of modern U.S. history and to encourage synthetic perspectives on social movements and the state, on gender, race, and labor, and on intellectual history and popular culture. 


\title{
SET THE WORLD ON FIRE 交
}

\author{
Black Nationalist Women \\ and the Global Struggle for Freedom
}

KEISHA N. BLAIN

\section{PENN}

UNIVERSITY OF PENNSYLVANIA PRESS

PHILADELPHIA 
Copyright (C) 2018 University of Pennsylvania Press

All rights reserved. Except for brief quotations used for purposes of review or scholarly citation, none of this book may be reproduced in any form by any means without written permission from the publisher.

\author{
Published by \\ University of Pennsylvania Press \\ Philadelphia, Pennsylvania 19104-4112 \\ www.upenn.edu/pennpress \\ Printed in the United States of America \\ on acid-free paper
}

2466810975531

\title{
Library of Congress Cataloging-in-Publication Data
}

Names: Blain, Keisha N., 1985- author.

Title: Set the world on fire : black nationalist women and the global struggle for freedom / Keisha N. Blain.

Other titles: Politics and culture in modern America.

Description: 1st edition. | Philadelphia : University of Pennsylvania Press, [2018] | Series: Politics and culture in modern America | Includes bibliographical references and index.

Identifiers: LCCN 2017026795 | ISBN 9780812249880 (hardcover : alk. paper)

Subjects: LCSH: Black nationalism-History -20th century. | African diaspora-History-20th century. | Pan-AfricanismHistory-20th century. | African American women-Political activity-History-20th century. | African American women political activists-History-20th century. | Women in politics-United States-History.

Classification: LCC E185.6 B65 2018 | DDC 320.54/60904-dc23

LC record available at https://lccn.loc.gov/2017026795 
FOR MOM, WITH LOVE 
